\title{
Kualitas dan Aktifitas Antibakteri Dadih Susu Sapi Mutan Lactococcus lactis terhadap Staphylococcus aureus, Escherechia coli dan Salmonella typii
}

\section{Quality and Antibacterial Activity of Mutant Cow Milk Dadih Lactococcus lactis on Staphylococcus aureus, Escherechia coli and Salmonella typii}

\section{S. Melia dan I. Juliyarsi}

Fakultas Peternakan Universitas Andalas

Kampus Unand Limau Manis Padang 25163

E-mail: sri.melia04@yahoo.com

(Diterima: 11 November 2010; Disetujui: 26 Januari 2011)

\begin{abstract}
Lactococcus lactis mutant dadih is fermented food made of cow's milk in a plastic tube with a $2 \%$ Lactococcus lactis and incubated at $30^{\circ} \mathrm{C}$ for 48 hours. The experiment result shown, the characteristics dadih barriers Lactococcus lactis mutants on antimicrobial activity against Staphylococcus aureus wider than antimicrobial activity against Escherechia typii coli and Salmonella. Lactococcus lactis mutant dadih contains $71,4 \%$ water, 0,93\% acidity, 5:02\% protein, $6: 39 \%$ fat, $18 \times 105 \mathrm{cfu} / \mathrm{g}$ total colony of Lactococcus lactis mutant, and essential amino acid.
\end{abstract}

Keyword: Dadih, mutan Lactococcus lactis dan bacteriocin

\section{PENDAHULUAN}

Produk susu fermentasi yang banyak dikosumsi sekarang ini, mengandung mikroorganisme hidup. Acidofilus milk, filmjolk, yoghurt, jungket, dan kefir adalah susu fermentasi yang mengandung bakteri asam laktat (BAL) tunggal atau gabungan dari beberapa BAL dan kamir. Produk susu fermentasi lainnya yang terkenal di Sumatera Barat adalah dadih, yang diperoleh dengan cara fermentasi alamiah dari susu kerbau dengan menggunakan wadah bambu (Sugitha, 1995).

Dadih merupakan salah satu produk olahan susu yang diperoleh melalui proses fermentasi. Produk-produk fermentasi susu oleh bakteri asam laktat telah dikenal sebagai minuman sehat karena dapat mencegah aktifitas dan pertumbuhan berbagai bakteri patogen.

Bakteri asam laktat telah banyak dimanfaatkan untuk mengawetkan produk makanan. Sifat pengawet dari bakteri asam laktat ini terutama disebabkan oleh adanya asam laktat, hidroperoksida dan bakteriosin. Bakteriosin adalah protein yang terdiri dari molekul-molekul yang dihasilkan dari bermacam-macam spesies bakteri yang mempengaruhi kegiatan bakterisidal terhadap bakteri yang mudah dipengaruhi olehnya (Einarson dan Lauzon 1994)

Harsanti (2001) dalam penelitiannya menemukan bahwa di dalam dadih susu kerbau yang mengandung bakteri asam laktat, didominasi oleh bakteri Lactococcus. Menurut Einarson dan Lauzon (1994), salah satu dari bakteriosin bakteri asam laktat dari genus Lactococcus adalah nisin yang telah digunakan sebagai pengawet selama beberapa dekade khususnya pada produk susu dan keju. Nisin merupakan bakteriosin pertama yang dipisahkan pada proses fermentasi bakteri asam laktat dan disetujui oleh FDA pada bulan April 1989 untuk mencegah pertumbuhan spora Clostridium botulinum dalam keju.

Bertolak dari pemikiran di atas, maka dalam penelitian ini dilakukan pengem-bangan kualitas dadih susu sapi yang mempunyai sifat unggul dari mutan Lactococcus lactis dengan kandungan bakteriosinnya yang dapat menghambat bakteri patogen (E. coli, S. aureus dan S. typii). Sebelumnya Mulyani (2001) telah dalam penelitiannya telah menghasilkan Mutan $L$. lactis dengan melakukan mutasi pada $L$. lactis yang diisolasi dari dadih susu kerbau dengan penambahan mutagen yaitu NTG $(\mathrm{N}$ metil-N'-nitro-N-nitosoguanin). 


\section{MATERI DAN METODE}

Penelitian dilakukan di Laboratorium Teknologi Hasil Ternak Fakultas Peternakan Universitas Andalas. Bahan-bahan yang digunakan dalam penelitian ini adalah susu sapi, media nutrient agar (NA), Lactose Brom Cresol Purple (LBCP), mutan L. lactis (Mulyani, 2001), bakteri uji $S$. aureus, E. coli dan S. typii. Alat-alat yang digunakan dalam penelitian ini antara lain portable autoclave, incubator, timbangan analitik, oven, refrigerator, hotplate stirrer dan peralatan gelas.

Penelitian ini menggunakan Rancangan Acak Lengkap (RAL) dengan lima perlakuan terhadap lama fermentasi yaitu 24 jam, 36 jam, 48 jam, 60 jam dan 72 jam dengan lima ulangan. Data yang diperoleh setelah diuji statistik dilanjukan dengan uji lanjutan Duncan's New Multiple Range Test (DNMRT) pada taraf $5 \%$.

Pembuatan dadih susu sapi mutan Lactococcus lactis Starter dadih.Tahap pertama dalam pembuatan starter adalah susu sapi dipanaskan pada suhu $60^{\circ} \mathrm{C}$ selama 60 menit sehingga sepertiga volumenya berkurang total padatannya menyamai susu kerbau. Kemudian segera didinginkan hingga suhu ruang. Selain itu, pemanasan ini bertujuan untuk membunuh bakteri patogen baik yang tahan panas maupun yang tahan dingin.

Mutan L. lactis yang telah disuspensikan dalam aquades steril dimasukkan ke dalam susu dengan menggunakan peralatan yang telah disterilisasi pada suhu $180{ }^{\circ} \mathrm{C}$ selama 30 menit. Kemudian dilakukan penambahan ekstrak bambu betung (Dendrocalamus asper) untuk menghasilkan aroma dadih yang khas seperti dadih susu kerbau (Sugitha,1995).

Susu yang telah diinokulasi dengan mutan $L$. lactis diinkubasi selama 48 jam pada suhu $30^{\circ} \mathrm{C}$, disebut sebagai starter dadih susu sapi mutan $L$. lactis, yang siap digunakan untuk pembuatan dadih dalam tabung atau tabung plastik.

Pembuatan Dadih dalam kemasan tabung plastik. Susu yang akan digunakan untuk membuat dadih dalam kemasan tabung plastik dipasteurisasi pada suhu $60{ }^{\circ} \mathrm{C}$ selama 60 menit. Tujuannya sama pada proses pembuatan starter. Kemudian susu yang telah dipanaskan, segera didinginkan pada suhu $30^{\circ} \mathrm{C}$ dan dipindahkan ke dalam kemasan tabung plastik.
Jumlah starter yang ditambahkan adalah $2 \%$. Selama proses fermentasi, gula yang terdapat dalam susu difermentasi oleh bakteri mutan L.lactis sehingga meng-hasilkan asam laktat yang menyebabkan turunnya $\mathrm{pH}$, akibatnya mengendapkan curd susu (Winarno dan Fardiaz, 1973). Pada penelitian ini diuji lama fermentasi mulai dari $24 \mathrm{jam}, 36 \mathrm{jam}, 48 \mathrm{jam}, 60$ jam dan 72 jam pada suhu $30^{\circ} \mathrm{C}$. Selanjutnya diuji karakteristik dadih susu sapi mutan L.lactis yang meliputi total koloni mutan L. lactis, tingkat keasaman, aktivitas bakteriosin dadih susu sapi mutan $L$. lactis terhadap mikroba patogen, yaitu Escherecia coli, $S$. aureus dan S. typii, karakteristik dadih susu sapi mutan L. lactis dan analisis asam amino. Variabel yang diukur dalam penelitian ini adalah Uji Kemampuan mutan L.lactis menghasilkan asam laktat, Perhitungan jumlah koloni, Total Keasaman (\% TTA), Uji Bakteriosin (hambatan antibakteri) dadih mutan L. lactis, Pengujian karakteristik dadih mutan L. lactis, Analisis Asam Amino

\section{HASIL DAN PEMBAHASAN}

\section{Uji kemampuan mutan Lactococcus lactis menghasilkan asam laktat}

Kemampuan mutan L. lactis dalam menghasilkan asam laktat diuji dengan menggunakan media spesifik yang mengandung Lactose Brom Cresol Purple (LBCP). Hasil menunjukkan dengan terbentuknya area berwarna kuning muda disekeliling koloni mutan lactococcus lactis yang dispotkan pada media agar, dengan diameter $20 \mathrm{~mm}$ (Gambar 1) Juwono et al., 1980) menjelaskan bahwa area bening ini menunjukkan adanya fermentasi laktosa menjadi asam laktat oleh mutan L. lactis.

\section{Perhitungan jumlah koloni}

Hasil analisis statistik memberikan hasil yang berbeda nyata $(\mathrm{P}<0,05)$ yaitu berkisar antara $50 \mathrm{x}$ $10^{5}$ sampai dengan $133 \times 10^{5}$ Colony Forming Unit per gram (CFU/g). Pada Tabel 1, dapat dilihat semakin meningkat waktu fermentasi maka semakin tinggi jumlah koloninya. Pada fermentasi setelah 48 jam memberikan hasil yang tidak berbeda nyata $(\mathrm{P}>0,05)$ dengan fermentasi selama 60 jam dan 72 jam. Sedangkan fermentasi yang berlangsung selama 24 jam tidak berbeda nyata $(\mathrm{P}>0,05)$ dengan fermentasi 36 jam.

Jurnal total koloni dadih mutan L. lactis, yang difermentasi selama 48 jam lebih tinggi memberikan hasil yang tidak bebeda nyata dengan 
lama fermentasi selama 60 jam dan 72 jam. Sedangkan fermentasi yang berlangsung 24 jam tidak berbeda nyata $(\mathrm{P}>0,01)$ dengan fermentasi 36 jam. Hal ini disebabkan karena pada fase awal pertumbuhan mikroba 24 jam dan 36 jam adalah fase adaptasi, sedangkan saat mencapai 48 jam tercapailah face log, yaitu mikroba berkembangbiak dengan cepat hingga mencapai fase stati pada lama fermentasi $60 \mathrm{jam}$ dan $72 \mathrm{jam}$.

Menurut Winarno dan Fardiaz (1997) menyatakan bahwa tahap tumbuh (accelarate phase) yaitu tahap terjadinya pembelahan dapat berlangsung bila bahan makanan cukup dan keadaan media optimum (suhu dan $\mathrm{pH}$ ). Setelah 48 jam terlihat tidak ada perbedaan yang nyata terhadap pertumbuhan koloni.

\section{Total keasaman (\% TTA)}

Hasil analisis keragaman pada pengukuran tingkat keasaman atau Total Titrasi Asam (\% TTA) dadih susu sapi mutan L.lactis pada beberapa level waktu fermentasi, memberikan hasil yang berbeda nyata $(\mathrm{P}<0,05)$ yaitu berkisar $0,72 \%$ sampai dengan $1,10 \%$. Uji lanjut DNMRT, memperlihatkan dadih yang difermentasi selama 24 jam berbeda nyata $(\mathrm{P}<0,05)$ dengan dadih yang difermentasi selama 48 jam (Tabel 2). Sedangkan dadih yang difermentasi salama 60 jam tidak berbeda nyata $(\mathrm{P}>0,05)$ dengan fermentasi selama 72 jam. Peningkatan keasaman dadih seiring dengan peningkatan total koloni bakteri.

Menurut Sugitha (1995) rata-rata keasaman dadih susu kerbau yang ada di Sumatera Barat adalah 1,42 \%, Sebelum susu difermentasi, susu segar memiliki tingkat keasaman yang berkisar antara $0,135 \%-0,175 \%$. Keasaman ini tidak hanya disebabkan oleh asam laktat, tapi secara garis besarnya disebabkan oleh kasein, asam posfat, karbon dioksida, citrat dan albumin. yang

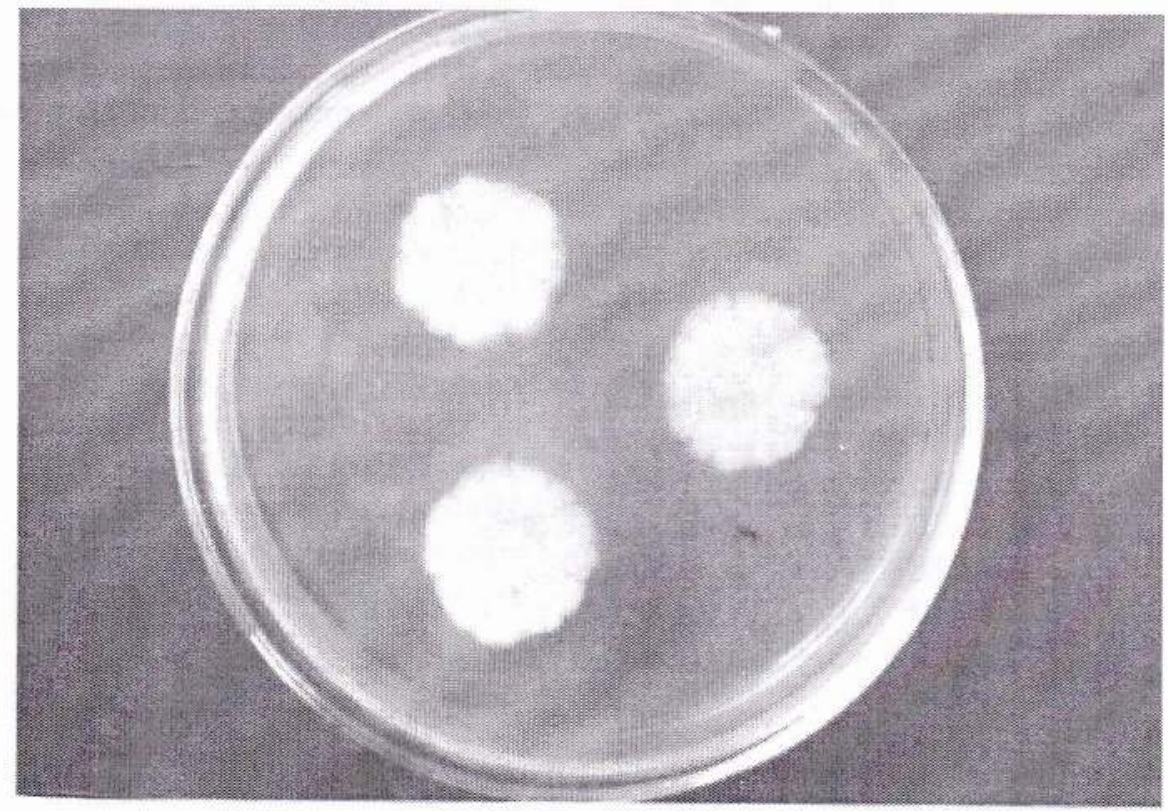

Gambar 1.Area kuning muda yang terbentuk disekitar koloni mutan L. lactis pada media LBCP agar

Tabel 1. Total koloni dadih susu sapi mutan Lactococcus lactis

\begin{tabular}{cc}
\hline Lama fermentasi (jam) & Total koloni $\left(10^{5} \mathrm{CFU} / \mathrm{g}\right)$ \\
\hline 24 & $50^{\mathrm{b}}$ \\
36 & $59^{\mathrm{b}}$ \\
48 & $118^{\mathrm{a}}$ \\
60 & $130^{\mathrm{a}}$ \\
72 & $133^{\mathrm{a}}$ \\
\hline
\end{tabular}

Keterangan : Superskrip yang berbeda pada kolom yang sama menunjukkan berbeda nyata $(\mathrm{P}<0,05)$ 
Tabel 2. Tingkat keasaman dadih susu sapi mutan L. lactis

\begin{tabular}{cc}
\hline Lama fermentasi (jam) & Tingkat keasaman $(\%$ TTA) \\
\hline 24 & $0,72^{\mathrm{d}}$ \\
36 & $0,81^{\mathrm{c}}$ \\
48 & $0,93^{\mathrm{b}}$ \\
60 & $1,18^{\mathrm{a}}$ \\
72 & $1,10^{\mathrm{a}}$ \\
\hline
\end{tabular}

Keterangan : Superskrip yang berbeda pada kolom yang sama menunjukkan berbeda nyata $(\mathrm{P}<0,05)$

Tabel 3. Aktifitas Hambatan Dadih Susu Sapi mutan L. lactis Hasil Penelitan.

\begin{tabular}{cccc}
\hline Lama fermentasi (jam) & \multicolumn{3}{c}{ Indeks mikroba uji } \\
\cline { 2 - 4 } & $E$. coli & S. aureus & $S$. typii $^{\mathrm{c}}$ \\
\hline 24 & $0,2^{\mathrm{b}}$ & $0,3^{\mathrm{c}}$ & $0,2^{\mathrm{b}}$ \\
36 & $0,2^{\mathrm{b}}$ & $0,4^{\mathrm{c}}$ & $0,2^{\mathrm{b}}$ \\
48 & $0,6^{\mathrm{a}}$ & $1,0^{\mathrm{a}}$ & $0,7^{\mathrm{a}}$ \\
60 & $0,5^{\mathrm{a}}$ & $0,6^{\mathrm{b}}$ & $0,6^{\mathrm{a}}$ \\
72 & $0,5^{\mathrm{a}}$ & $0,6^{\mathrm{b}}$ & $0,6^{\mathrm{a}}$ \\
\hline
\end{tabular}

Keterangan : Superskrip yang berbeda pada kolom yang sama menunjukkan berbeda nyata $\quad(P<0,05)$

mempengaruhi tingkat keasaman dadih adalah lamanya dadih disimpan dan banyaknya jenis bakteri perombak. Semakin lama dadih disimpan semakin meningkat keasamannya dan makin banyak jumlah bakteri yang merombak laktosa menjadi asam laktat, sehingga asam laktat yang terbentuk maksimal dan menyebabkan dadih menjadi asam (Sayuti, 1993). Hal yang sama tampak pada peningkatan total koloni dadih susu sapi mutan L. lactis, seiring dengan meningkatnya keasaman.

\section{Uji bakteriosin (hambatan antibakteri) dadih mutan $L$. lactis}

Dadih dengan beberapa level waktu fermentasi yaitu 24 jam, 36 jam, 48 jam, 60 jam dan 72 jam memperlihatkan aktifitas hambatan terhadap tiga mikroba patogen yang diuji yaitu $E$. coli, S. aureus dan S. typii (Tabel 3).

Indeks mikroba yang menunjukkan hambatan dadih terhadap $E$. coli berkisar antara 0,2 sampai dengan 0,6. Analisis statistik memberikan hasil yang sangat berbeda nyata $(\mathrm{P}<0,05)$ pada setiap perlakuan sehingga dapat dilanjutkan dengan uji DNMRT.
Dadih yang difermentasi selama 24 jam tidak berbeda nyata $(\mathrm{P}>0,05)$ aktifitas hambatannya terhadap E.coli dengan dadih yang difermentasi selama $36 \mathrm{jam}$. Aktifitas hambatan dadih yang difermentasi selama 48 jam terhadap E.coli tidak berbeda nyata dengan aktifitas hambatannya pada fermentasi selama $60 \mathrm{jam}$ dan $72 \mathrm{jam}$ $(\mathrm{P}>0,05)$. Sedangkan aktifitas hambatan dadih yang difermentasi selama 24 jam dan 36 jam terhadap $E$.coli berbeda nyata dengan aktifitas hambatan pada fermentasi selama 48 jam, 60 jam dan $72 \mathrm{jam}(\mathrm{P}<0,05)$.

Adanya areal bening (zona hambatan) yang terbentuk disekeliling kertas cakram menunjukkan adanya aktifitas hambatan dadih terhadap $E$. coli Sebagai pembanding digunakan nisin (N 5764), yang memperlihatkan aktifitas hambatan disekeliling kertas cakram yang telah dicelupkan ke larutan nisin, menghasilkan indeks mikroba 1,0.

Zona hambatan yang terjadi disebabkan oleh adanya senyawa tertentu yang bersifat anti mikroba (bakteriosin) yang dihasilkan oleh mutan L. lactis yang digolongkan ke dalam jenis bakteri asam laktat. Aktifitas hambatan yang ditunjukkan dadih terhadap $S$. aureus memberikan hasil yang berbeda nyata $(P<0,05)$. Pada setiap perlakuan Secara umum indeks mikroba berkisar antara 0,3 sampai dengan 10 . 
Fermentasi dadih selama 24 jam memberikan hasil yang tidak berbeda nyata terhadap aktifitas hambatan terhadap $S$. aureus pada fermentasi dadih selama 36 jam $(\mathrm{P}>0,05)$. Aktifitas hambatan dadih terhadap $S$. aureus pada fermentasi selama 48 jam berbeda nyata dengan aktifitas hambatan dadih yang difermentasi selama 60 jam dan 72 jam $(\mathrm{P}<0,05)$. Sebagai pembandingnya digunakan nisin (5764), yang diuji hambatannya terhadap S.aureus, menghasilkan indeks mikroba dengan nilai 1,4. $S$. aureus adalah bakteri penyebab keracunan yang memproduksi enterotoksin. Menurut Ferber (2001), nisin yang dihasilkan oleh $L$. lactis yaitu spesies bakteri yang terdapat di dalam susu, pada dosis rendah dapat menghambat bakteri yang mengkontaminasi makanan. Ditambahkan oleh Engelke et al (1992) Nisin secara aktifmenyerang bakterigram positifdan spora.

Pada Tabel 3, dapat diperhatikan aktifitas hambatan tertinggi ditunjukkan olek $S$. aureus, dibandingkan dengan $E$. coli dan S. typii. S. aureus yang tergolong bakteri gram positif sangat efektif dihambat oleh bakteriosin, daripada $E$. coli dan $S$. typii tergolong bakteri gram negatif. Menurut Eckner (1991 dan Benkerroun, et al., 1998), nisin merupakan bakteriosin yang memiliki spektrum aktifitas paling luas. Senyawa ini mampu menghambat pertumbuhan banyak bakteri gram positif dan juga diketahui menghambat beberapa Salmonella. Pada penelitian ini dilihat hambatan dadih terhadap S. typii.

Hasil analisis statistik menunjukkan hambatan dadih terhadap $S$. typii memberikan pengaruh yang berbeda sangat nyata $(\mathrm{P}<0,05)$, yaitu berkisar antara 0,2 sampai dengan 0,7 . Uji lanjut DNMRT menjelaskan bahwa aktifitas hambatan dadih terhadap $S$. typii pada fermentasi selama 24 jam tidak berbeda nyata dengan fermentasi selama 36 jam $(\mathrm{P}>0,05)$. Tetapi kedua perlakuan ini berbeda nyata aktifitas hambatannya ter-hadap $S$. typii pada dadih yang difermentasi selama 48 jam $(\mathrm{P}<0,05)$. Sama halnya dengan $E$. coli dan $S$. aureus, Salmonella juga mengalami kenaikan aktifitas hambatan setelah 24 jam.

\section{Pengujian karakteristik dadih mutan L.lactis}

Pada Tabel 4 dapat dilihat hasil analisis karakteristik dadih susu sapi mutan $L$. lactis dan kualitas dadih susu L. lactis (Sugitha, 1995).
Dadih susu sapi mutan L.lactis memiliki kadar air 74,47 \%, lebih rendah dari pada dadih susu sapi L. lactis. Kondisi ini juga terlihat pada sifat kekentalan dadih susu sapi mutan $L$. lactis yaitu $10,5 \mathrm{Cp}$, yang lebih tinggi dari dadih susu sapi $L$. lactis dengan nilai kekentalan 7,81 Cp.

Menurut Sugitha dan Djalil (1989) faktor yang mempengaruhi viskositas adalah konsentrasi dan keadaan protein, konsentrasi dan keadaan lemak, suhu dan lamanya susu disimpan. Kenaikan kadar protein dapat meningkatkan viskositas. Pengaruh kadar lemak terhadap viskositas terutama berubahnya daya friksi lemak karena perbedaan ukuran globula lemak dan tingkat pembentukan kluster globula lemak.

Begitu juga dengan kadar lemak dadih yang lebih tinggi dari dadih susu sapi mutan L.lactis. Menurut Walstra, et al. (2005) kadar lemak susu segar adalah 3,66 \%. Setelah difermentasi menjadi dadih meningkat menjadi 6,39\%.

Kadar protein dadih susu sapi mutan L.lactis ini lebih tinggi dari susu segar. Hal ini dapat terjadi karena selamafermentasi, protein yang merupakan makromolekul dikatabolisme menjadi bentuk sederhana yaitu berupa peptide-petida rantai pendek terdiri dari dua atau lebih asam amino yang dihubungkan dengan ikatan kovalen sehingga komponen asam amino lebih mudah dicerna mudah dicerna sehingga dadih sebagai produk susu fermentasi dapat digunakan pada penderita lactose intolerance karena memilikiprotein yang sudah lebih mudah dicerna dalam bentuk asam amino dengan adanya bantuan dari bakteri asam laktat. Berdasarkan hasil penelitian Mulyani (2001), kecepatan mutan L.lactis dalam berkembangbiak lebih cepat dibanding dengan L.lactis sebelum mutasi.

\section{Analisis asam amino}

Dadih yang dihasilkan, diidentifikasi jenis asam amino yang dikandungnya (Tabel 5). Hasil asam amino dadih susu sapi mutan L.lactis terdiri dari 17 jenis asam amino, yang mengandung 9 asam amino esensial. Ada beberapa asam amino yang tidak terdeteksi pada gambar spektrum asam amino yaitu triptofan, glutamin dan asparagin. 
Tabel 4. Karakteristik dadih susu sapi

\begin{tabular}{lcc}
\hline \multicolumn{1}{c}{ Komponen } & $\begin{array}{c}\text { Dadih Susu Sapi } \\
\text { Mutan L.lactis* }\end{array}$ & Dadih susu sapi L.lactis** \\
\hline Air & $74,47 \%$ & $79,72 \%$ \\
Keasaman & $0,93 \%$ & $1,21 \%$ \\
Protein & $5,62 \%$ & $4,7 \%$ \\
Lemak & $6,39 \%$ & $5,10 \%$ \\
Total koloni & $118 \times 105 \mathrm{CFU} / \mathrm{g}$ & $178 \times 10^{5} \mathrm{CFU} / \mathrm{g}$ \\
pH & 4,80 & 4,6 \\
Kekentalan & $10,5 \mathrm{Cp}$ & $7,81 \mathrm{Cp}$ \\
\hline
\end{tabular}

*Sugitha (1995)

Tabel 5. Hasil analisis asam amino dadih susu sapi mutan L.lactis**

\begin{tabular}{lc}
\hline \multicolumn{1}{c}{ Jenis asam amino } & Konsentrasi (\%) \\
\hline Asam aspartat & 0,151 \\
Asam glutamat & 0,129 \\
Serin & 0,135 \\
Glisin & 0,154 \\
Histidin & 0,182 \\
Arginin & 0,242 \\
Threonin & 0,225 \\
Alanin & 0,190 \\
Prolin & 0,168 \\
Tirosin & 0,221 \\
Valin & 0,198 \\
Methionin & 0,297 \\
Sistin & 0,296 \\
Isoleusin & 0,252 \\
Leusin & 0,257 \\
Phenil alanin & 0,132 \\
Lisin & 0,264 \\
\hline
\end{tabular}

**) Laboratorium Biokimia PAU-IPB Bogor (2007)

\section{KESIMPULAN}

Hasil penelitian kemampuan mutan L.lactis menghasilkan asam laktat pada media LBCP agar memperlihatkan adanya pemecahan laktosa menjadi asam laktat dengan terbentuknya area kuning muda disekitar koloni yang berdiameter 20 mm Dadih mutan L. lactis $2 \%$, memperlihatkan kemampuan bakteriosin dalam menghambat aktifitas mikroba patogen yaitu $E$. coli, $S$. aureus dan S. typii. Hambatan tertinggi ditunjukkan oleh dadih yang difermentasi selama 48 jam terhadap S.aureus dengan indeks mikroba 1,0, E. coli 0,6 , dan S.typii 0,7.

Pengujian kualitas dadih yang difermentasi selama 48 jam menghasilkan total koloni $118 \times 10^{5}$
CFU/g, tingkat keasaman $0,93 \%$, kadar air $74,47 \%$ , kadar protein 5,62 \%, kadar lemak 6,39\%, pH 4,80 dan kekentalan 10,5 Cp. Jenis asam amino esensial yang terdapat pada dadih adalah histidin, arginin, threonin, valin, methionin, isoleusin, leusin, phenil alanin, dan lisin.

\section{DAFTAR PUSTAKA}

Benkerroun, N., Hafida O., dan WS. Sandine. 1998. Effect of nisin on yogourt starter and fffect of nisin on growth and survival Listeria monocytogenes during fermentation and Storage of Yogourt. J. Appl. Biotecnol. Vol 34(1):225-236. 225-236. 
Walstra, P., Jan T.M. W, and Tom J.G. 2005. Dairy Science and Technology. CRC.

Eckner, K.F. 1991. Bacteriocin and Food Application. Laboratory Manual in General Microbilogy. University of Philipines Press.

Einarsson, H. dan H. Lauzon, 1994. Biopreservative of brine shrimp by bacteriocins from lactic acid bacteria. J. Appl. And Enviroment. Microbiol. 36(12) :669-676.

Engelke, G., Z. Gutowski-Eckel, M. Hammelmann, K. dan Entian, 1992. Biosynthesis of Lantibiotic nisin genomic organization and membran localization $\mathrm{ff}$ NisB protein. J. Appl. Enveroment. Microbiol, Vol 5 (2) : 3730-3734

Harsanti, S.U., 2001. Uji ioaktifitas Bakteriosin Pada Dadih di Sumatera Barat. Thesis Pasca Sarjana. UNAND. Padang.

Juono, J., Hartadi, Kabirun, Suhadi dan Soesanto. 1980. Pedoman Praktikum Mikrobiologi untuk Perguruan tinggi. Departemen
Mikrobiologi Fakultas Pertanian, UGM. Yogyakarta.

Mulyani, 2001. Skrining Mutan dan Uji Aktifitas Bakteriosin Dari Bakteri Asam Laktat. Tesis Program Pascasarjana. UNAND.

Sayuti, K, 1993. Mempelajari Mutu Dadih Pada Lama Penyimpanan dan Jenis Bambu yang Berbeda. Skripsi Sarjana. Fakultas Pertanian. UNAND. Padang.

Sugitha, I.M., 1995. Dadih: Olahan Susu Kerbau Tradisional Minang, Manfaat, Kendala, Dan Prospeknya dalam Era Industrialisasi Sumatera Barat. Seminar Sehari Penerapan Teknologi Hasil Ternak Untuk Peningkatan Gizi Masyarakat. Fakultas Petarnakan- Western University Training Centre. Padang.

Sugitha dan Djalil. 1989. Susu: Pengolahan dan Teknologinya. Teknologi Hasil Ternak, Fakultas Peternakan, Universitas Andalas. Padang.

Winarno dan Fardiaz. 1997. Dasar Teknologi Pengolahan. IPB. Bogor. 